\title{
ANALISIS PENGARUH CUSTOMER PERCEIVED VALUE PADA KEPUASAN DAN KESETIAAN NASABAH BANK BRISYARIAH WAHID HASYIM
}

\author{
Laily Maknin Zubaedah, S.T., M.BA. \\ lailymaknin@gmail.com
}

\begin{abstract}
ABSTRAK
Tujuan dari penelitian ini adalah untuk menganalisis pengaruh nilai perceived customer terhadap kepuasan nasabah Bank BRISyariah Wahid Hasyim, untuk menganalisis pengaruh nilai perceived customer terhadap loyalitas pelanggan Bank BRISyariah Wahid Hasyim, dan untuk menganalisis pengaruh kepuasan terhadap loyalitas pelanggan Nasabah Bank BRISyariah Wahid Hasyim. Penelitian ini menggunakan metode Uji Hipotesis dan Metode Analisis Deskriptif, dengan persepsi pelanggan dianggap sebagai variabel bebas, maka kepuasan dan loyalitas sebagai variabel dependen. Data sampel utama diambil di Balai Perbankan Bank BRISyariah Cabang Wahid Hasyim menggunakan Metode Sampling Kenyamanan dengan meminta 200 nasabah untuk mengisi kuesioner.

Skala yang digunakan dalam kuesioner ini adalah Skala Likert, yang memiliki lima pilihan potensial (sangat setuju, setuju, netral, tidak setuju, sangat tidak setuju). Uji Validitas pada alat ukur ini (kuesioner) menggunakan Metode Analisis Faktor yang memiliki faktor pembebanan \pm 0,50 atau lebih (Practical Significance Method). Kemudian, Uji Kehandalan menggunakan Cronbach Alpha Score dengan tingkat kepercayaan 95\%. Hasil uji validitas dan reliabilitas valid dan reliabel. Analisis korelasi antara ketiga variabel ini akan dijelaskan dengan Multiple Regression Analysis dan t-Test.

Hasil pengujian hipotesis dalam penelitian ini membuktikan bahwa Nilai Fungsional signifikan berpengaruh positif terhadap kepuasan nasabah terhadap Bank BRISyariah Wahid Hasyim, Nilai Emosional signifikan berpengaruh positif terhadap kepuasan nasabah terhadap Bank BRISyariah Wahid Hasyim, Nilai Sosial berpengaruh positif signifikan terhadap kepuasan nasabah Bank BRISyariah Wahid Hasyim, dan Kepuasan positif berpengaruh signifikan terhadap loyalitas nasabah Bank BRISyariah Wahid Hasyim.

Kata kunci: Customer Perceived Value, Satisfaction, dan Loyalty.
\end{abstract}




\section{PENDAHULUAN}

Industri Perbankan Syariah di Indonesia dalam beberapa tahun terakhir berkembang makin cepat dan agresif. Hal ini ditandai dengan rata-rata pertumbuhan aset perbankan syariah selama lima tahun terakhir mencapai 40 persen, jauh melampaui pertumbuhan perbankan konvensional yang hanya sekitar 20 persen. Menurut Rama (2012), sekitar 180 juta penduduk saat ini, ingin merasakan manfaat produk dan layanan syariah. Orang mulai mencari dan beralih dari bank konvensional ke bank syariah. Hal ini terjadi dikarenakan adanya manfaat yang diberikan oleh perbankan syariah. Ini mencerminkan bahwa pasar perbankan syariah sangat besar dan masih sangat terbuka lebar.

Seiring dengan itu, pihak perbankan syariah terus menerus memberikan edukasi kepada nasabah, sehingga meningkatkan kesadaran dan kebutuhan nasabah terhadap kehadiran bank syariah. Hal ini langsung ditangkap sebagai peluang oleh industri perbankan syariah di Indonesia, sehingga semakin banyak bank-bank konvensional yang menyediakan layanan syariah bagi para nasabahnya, baik itu berupa Unit Usaha Syariah maupun yang sudah spin-off menjadi Bank Umum Syariah.

Peluang ini pun ditangkap pula oleh PT. Bank BRISyariah yang merupakan salah satu bank umum syariah terbesar dan akan terus berkembang yang ada di Indonesia. PT. Bank BRISyariah menjadi Bank Umum Syariah ke empat di Indonesia setelah PT. Bank Rakyat Indonesia (Persero), Tbk berhasil mengakuisisi Bank Jasa Artha pada tanggal 19 Desember 2007 dan setelah mendapatkan izin dari Bank Indonesia pada 16 Oktober 2008, maka pada tanggal 17 November 2008 PT. Bank BRISyariah resmi beroperasi.

Bank BRISyariah ikut meramaikan industri perbankan syariah yang tumbuh dan berkembang pesat di Indonesia. Karena banyaknya pemain di dalam industri perbankan syariah ini, pada akhirnya memunculkan persaingan yang ketat. Setiap Bank Syariah, baik itu yang masih berupa Unit Usaha Syariah maupun yang sudah menjadi Bank Umum Syariah, berlombalomba mengatur strategi pemasaran yang tepat dan efektif untuk bisa meraih pasar dan juga mempertahankan para nasabah mereka agar tidak berpindah ke bank lain. Meskipun strategi pemasaran yang tepat dan efektif itu penting dalam meraih bisnis, namun hal itu bukanlah satusatunya faktor yang menyebabkan suatu bank syariah menjadi sukses dalam memenangkan sebuah persaingan bisnis.

Saat ini Bank BRISyariah tengah mengoptimalkan layanannya untuk nasabah, baik dari segi produk, layanan, serta kemudahan-kemudahan yang beragam. Selain itu, kualitas layanan 
yang diberikan oleh setiap bagian yang berhubungan langsung dengan nasabah setiap waktu lebih ditingkatkan. Boleh dikatakan, saat ini Bank BRISyariah hadir dengan membawa solusi bagi para nasabahnya yang ingin bertransaksi perbankan di bank syariah dengan cara mengenali lebih dalam tentang nilai-nilai yang sebenarnya diinginkan oleh nasabah.

Meskipun bank telah berusaha untuk melakukan beberapa cara untuk membangkitkan nilai-nilai yang dirasakan nasabahnya, tetap saja bank tersebut pastinya pernah berpengalaman mendapatkan nasabah-nasabah yang tidak puas/dissatisfaction pada produk maupun layanannya (Johnston, 1997 dalam roig et al., 2006). Selain itu, masih banyak pula nasabah yang mau berpindah ke bank lain tanpa ada perasaan bersalah. Berdasarkan latar belakang diatas maka penelitian ini ingin menganalisa hubungan antara customer perceived value, kepuasan, dan kesetiaan nasabah, dengan lokasi penelitian dilakukan di Bank BRISyariah Kantor Cabang Wahid Hasyim, yang berada di daerah Tanah Abang, Jakarta Pusat.

Tujuan penelitian ini adalah untuk menguji pengaruh customer perceived value pada kepuasan nasabah Bank BRISyariah Kantor Cabang Wahid Hasyim, dimana customer perceived value yang diuji adalah Functional Value, Emotional Value, dan Social Value. Dan untuk menguji pengaruh kepuasan pada kesetiaan nasabah Bank BRISyariah Kantor Cabang Wahid Hasyim.

\section{KAJIAN PUSTAKA}

\section{Customer Perceived Value (CPV)}

Menurut Zeithaml (1988), definisi customer perceived value (CPV) atau nilai pelanggan adalah sebagai berikut:

"perceived Value is the consumer's overall assessment of the utility of a product base on perception of what is received and what is given."

Kutipan diatas mempunyai arti bahwa Perceived Value merupakan keseluruhan penilaian konsumen terhadap penggunaan suatu produk atas apa yang diterima dan yang diberikan oleh produk tersebut.

Terdapat dua konsep penting tentang customer perceived value (CPV) yaitu sebagai berikut:

“CPV is a result from the consumers' pre-purchase perception (expectation), evaluation during the transaction (expectation versus received), and post-purchase (after use) assessment 
(expectation versus received) dan CPV involves a divergence between the benefits received and sacrifices given."

Dari konsep diatas dapat dikatakan bahwa customer perceived value merupakan hasil dari tiga tahapan proses yang dialami oleh seorang konsumen, yang pertama yaitu persepsi sebelum terjadinya pembelian atau ekspektasi konsumen. Yang kedua evaluasi yang dilakukan oleh seorang konsumen pada saat terjadinya transaksi, dan yang ketiga pada saat pasca pembelian atau penilaian yang diberikan oleh konsumen setelah terjadinya pembelian.

Selain itu, CPV juga merupakan penilaian konsumen yang dilakukan dengan cara membandingkan antara 'manfaat' yang diterima dengan 'pengorbanan' yang telah dikeluarkan untuk memperoleh sebuah produk yang diinginkan. Yang termasuk dalam 'manfaat' disini adalah nilai-nilai yang diinginkan oleh pelanggan, contohnya seperti kualitas (Monroe, 1990). Sedangkan yang dimaksud dengan'pengorbanan' merupakan keuangan (harga) dan nonkeuangan (waktu, usaha) (Cronin, et al., 2000; Dods, Monroe, \& Grewal, 1991; Monroe, 1990).”

Untuk memaksimalkan customer perceived value, perusahaan harus pula meningkatkan nilai-nilai yang dirasakan oleh pelanggan seperti meningkatkan kualitas produk, dan/atau mengurangi pengorbanan pelanggan seperti harga yang harus dibayar, serta waktu dan usaha untuk melakukan pembelian. Perceived value merupakan hal yang sangat penting yang menentukan intensitas loyalitas konsumen (Parasuraman 1997, Woodruff 1997).

Ketika sedang menginvestigasi konsep dan dimensi perceived value, terdapat dua pendekatan mayor yang digunakan sebagai berikut (Roig et al., 2006):

a. Pendekatan yang pertama yaitu mendefinisikan perceived value sebagai sebuah konstruk yang terdiri dari dua bagian, yaitu manfaat yang diterima pelanggan (ekonomi, sosial, dan relational) dan pengorbanan yang telah dikeluarkan oleh nasabah (harga, waktu, usaha, resiko, dan kenyamanan) (Dodds et al., 1991; Rapp and Collins, 1991,1996; Grewal et al., 1998; Cronin et al. 2000; Bigne et al., 2000 yang dikutip oleh Roig et al., 2006).

b. Pendekatan kedua didasarkan pada konsepsi perceived value sebagai sebuah konstruk multidimensi (Woodruff, 1997; De Ruyter et al., 1997 and 1998; Sweeney and Soutar, 2001; Sanches et al., 2006 yang dikutip oleh Roig et al., 2006). Penggabungan nilai seperti functional dimension, sebuah dimensi efektif yang menggambarkan aspek emosional dan aspek sosial dari individu, menguji subyek yang berkaitan dengan perilaku pembelian. 
Functional value didefinisikan sebagai penilaian ekonomi individu yang rasional. Kualitas produk dan kualitas layanan, termasuk dalam dimensi ini. Dimensi yang efektif ini dibagi menjadi dimensi emosional (berhubungan dengan perasaan atau emosi internal) dan dimensi sosial (berhubungan dengan dampak sosial atas pembelian).

\section{Satisfaction (Kepuasan)}

Menurut Daryanto (2011), mencapai tingkat kepuasan pelanggan tertinggi adalah tujuan utama pemasaran. Ketika pelanggan merasa puas akan pelayanan yang didapatkan pada saat proses transaksi dan juga puas akan akan barang atau jasa yang mereka dapatkan, besar kemungkinan mereka akan kembali lagi dan melakukan pembelian-pembelian yang lain dan juga akan merekomendasikan pada teman-teman dan keluarganya tentang perusahaan tersebut dan produk-produknya. Juga kecil kemungkinannya mereka berpaling ke pesaing-pesaing perusahaan. Mempertahankan kepuasan pelanggan dari waktu ke waktu akan membina hubungan yang baik dengan pelanggan. Hal ini dapat meningkatkan keuntungan perusahaan dalam jangka panjang.

Spreng et al. (1996) mendefinisikan sebagai berikut:

“perasaan puas pelanggan timbul ketika konsumen membandingkan persepsi mereka mengenai kinerja produk atau jasa dengan harapan mereka."

Tse dan Wilson (1988) menguraikan dua variabel utama yang menentukan kepuasan pelanggan, yaitu expectations dan perceived performance. Apabila perceived performance melebihi expectations maka pelanggan akan puas, tetapi apabila sebaliknya maka pelanggan merasa tidak puas.

Menurut Engel, Blackwell, and Miniard (1995) dalam Sumarwan (2004) mendefinisikan kepuasan adalah sebagai berikut:

"Satisfaction is defined here as a post consumption evaluation that a chosen alternative at least or exceeds expectation".

Maksud dari kepuasan disini dapat diartikan sebagai suatu kondisi evaluasi pasca konsumsi dimana apa yang diterima atau dinikmati tersebut melebihi harapan.

Kotler dan Keller (2006), menyatakan sebagai berikut: 
"kepuasan pelanggan adalah perasaan senang atau kekecewaan seseorang setelah membandingkan kinerja atau hasil yang dirasakan dibandingkan dengan harapannya."

Oliver and De Sarbo (1988) memandang tingkat kepuasan (satisfaction) timbul karena adanya suatu transaksi khusus antara produsen dan konsumen yang merupakan kondisi psikologis yang dihasilkan ketika faktor emosi mendorong harapan (expectations) dan disesuaikan dengan pengalaman mengonsumsi sebelumnya (perception). Selain itu, menurut Zeithaml et al. (1996) kepuasan pelanggan merupakan perbandingan antara layanan yang diharapkan (expectations) dan kinerja (perceived performance).

Dalam Daryanto (2011), Zeithaml dan Bitner (2003) menyatakan bahwa ada beberapa faktor yang mempengaruhi kepuasan pelanggan, antara lain sebagai berikut:

a. Fitur produk dan jasa. Kepuasan pelanggan terhadap produk atau jasa secara signifikan dipengaruhi oleh evaluasi pelanggan terhadap fitur produk atau jasa. Untuk jasa perbankan, fitur yang penting meliputi karyawan yang sangat membantu dan sopan, ruang transaksi yang nyaman, sarana pelayanan yang menyenangkan, dan sebagainya.

b. Emosi pelanggan. Emosi juga dapat mempengaruhi persepsi pelanggan terhadap produk dan jasa. Pikiran atau perasaan pelanggan (good mood atau bad mood) dapat mempengaruhi respon pelanggan terhadap jasa. Emosi positif seperti perasaan bahagia, senang, gembira akan meningkatkan kepuasan pelanggan. Sebaliknya, emosi negatif seperti kesedihan, duka, penyesalan dan kemarahan dapat menurunkan tingkat kepuasan.

c. Atribusi untuk keberhasilan atau kegagalan jasa. Atribusi penyebab yang dirasakan dari suatu peristiwa mempengaruhi persepsi dan kepuasan. Ketika pelanggan dikejutkan dengan hasil produk/jasa, pelanggan cenderung untuk melihat alasan, dan penilaian mereka terhadap alasan dapat mempengaruhi kepuasan. Misalnya, ketika nasabah gagal menarik uang dari ATM maka ia akan mencari alasan mengapa ATM tidak dapat berfungsi. Apabila tidak berfungsinya ATM disebabkan oleh matinya aliran listrik PLN maka hal ini tidak akan mempengaruhi kepuasannya terhadap bank tertentu.

d. Persepsi terhadap kewajaran dan keadilan (equity and fairness). Kepuasan pelanggan juga dipengaruhi oleh persepsi pelanggan terhadap kewajaran dan keadilan.

e. Pelanggan lain, keluarga dan rekan kerja. Kepuasan pelanggan juga dipengaruhi oleh orang lain. 


\section{Loyalty (Kesetiaan)}

Sumarwan (2004) mendefinisikan loyalitas konsumen sebagai berikut:

"konsumen yang merasa puas terhadap produk atau merek yang dikonsumsi atau dipakai, dan akan membeli ulang produk tersebut."

Pembelian berulang yang terus menerus dari produk dan merek yang sama akan menunjukkan loyalitas konsumen terhadap merek tersebut.

Dua kondisi penting yang berhubungan dengan loyalitas adalah retensi pelanggan, yang menjelaskan lamanya hubungan dengan pelanggan, dan total pangsa pelanggan, yang menjelaskan prosentase dari anggaran pelanggan yang dibelanjakan kepada suatu perusahaan. Idealnya, perilaku pembelian pelanggan yang loyal mencerminkan kedua kondisi ini. Loyalitas pelanggan yang meningkat akan mengakibatkan hasil positif berupa profitabilitas yang lebih tinggi, retensi pegawai yang lebih tinggi, dan basis keuangan yang lebih stabil (Suwarman et al., 2011).

Zeithaml et al. (1996) dalam Sumarwan et al. (2011) menyatakan dengan beberapa atribut pada pengukuran kesetiaan, yaitu : 1) mengatakan hal yang positif tentang perusahaan kepada orang lain, 2) merekomendasikan perusahaan kepada orang lain yang meminta saran, 3) mempertimbangkan bahwa perusahaan merupakan pilihan pertama dalam melakukan pembelian jasa, dan 4) melakukan lebih banyak bisnis atau pembelian dengan perusahaan pada beberapa tahun mendatang.

Tjiptono (2001) dalam Suwarman et al. (2011) mengemukakan enam indikator yang bisa digunakan untuk mengukur loyalitas konsumen, yaitu 1) pembelian berulang, 2) kebiasaan mengkonsumsi merek tersebut, 3) selalu menyukai merek tersebut, 4) tetap memilih merek tersebut, 5) memiliki keyakinan bahwa merek tersebut yang terbaik, dan 6) merekomendasikan merek tersebut pada orang lain.

\section{Hubungan Customer Perceived Value. Satisfaction, dan Loyalty.}

Ada hubungan yang kuat antara nilai nasabah dengan kepuasan nasabah (Durvasula et al. (2004) dalam Sumarto (2007). Agar nasabah puas, jasa yang dibeli, dimiliki, dan digunakan harus memiliki nilai (Zeithaml, 1988 dalam Sumarto, 2007). Artinya jika suatu badan usaha ingin mencapai keberhasilan, harus mampu memberikan nilai kepada para pelanggannya lebih 
baik dari para pesaingnya (Naumann, 1995 dalam Sumarto, 2007). Sheth et al. (1991) dalam Sumarto (2007) menunjukkan 3 nilai penting yang harus diperoleh pelanggan, yaitu functional value, emotional value, dan social value.

Kepuasan nasabah sangat mempengaruhi loyalitas nasabah (Caruna, 2002 dalam Sumarto, 2007). Nasabah yang loyal adalah mereka yang puas dengan produk atau jasa tertentu sehingga mempunyai antusiasme untuk memperkenalkannya kepada siapapun yang mereka kenal. Loyalitas nasabah merupakan reaksi atau akibat dari terciptanya kepuasan nasabah sebagai wujud keberhasilan pelayanan yang berkualitas dalam memenuhi harapan nasabah.

Menurut Tjiptono (2002) dalam Suwarman et al. (2011), terciptanya kepuasan dapat memberikan beberapa manfaat diantaranya hubungan antara perusahaan dan pelanggan menjadi harmonis, memberi dasar bagi pembelian ulang, menciptakan loyalitas pelanggan, serta rekomendasi dari mulut ke mulut yang menguntungkan perusahaan. Menurut Kotler (2003) dalam Suwarman et al. (2011), hubungan antara kepuasan dan loyalitas adalah saat dimana konsumen mencapai tingkat kepuasan tertinggi yang menimbulkan ikatan emosi kuat dan komitmen jangka panjang dengan merek perusahaan. Produk dan layanan yang berkualitas berperan penting dalam membentuk kepuasan konsumen, selain juga erat kaitannya dalam menciptakan keuntungan bagi perusahaan. Semakin berkualitas produk dan layanan yang diberikan perusahaan kepada konsumennya, kepuasan yang dirasakan akan semakin tinggi.

Apabila Bank dapat meningkatkan kepuasan kepada nasabahnya, maka kesetiaan juga akan meningkat, demikian pula sebaliknya apabila suatu Bank tidak dapat memberikan kepuasan kepada nasabahnya maka secara otomatis kesetiaan nasabah juga tidak akan terbentuk.

\section{Hipotesis Penelitian}

Penelitian ini mencoba untuk menguji apakah terdapat pengaruh antara customer perceived value pada kepuasan dan kesetiaan nasabah Bank BRI Syariah Kantor Cabang Wahid Hasyim dengan menggunakan beberapa hipotesis di bawah ini:

\section{Customer Perceived Value dan Satisfaction (Kepuasan)}

Sheth et al., (1991) dalam Sumarto (2007) menunjukkan tiga nilai penting (customer perceived value) yang harus diperoleh nasabah yaitu functional value, emotional value dan social value.

\section{Functional Value dan Satisfaction (Kepuasan)}

$\mathrm{H}_{0} 1 \mathrm{a}$ : Functional Value tidak berpengaruh positif pada kepuasan nasabah.

H1a: Functional Value berpengaruh positif pada kepuasan nasabah. 


\section{Emotional Value dan Satisfaction (Kepuasan)}

$\mathrm{H}_{0} 1$ b: Emotional Value tidak berpengaruh positif pada kepuasan nasabah.

H1b: Emotional Value berpengaruh positif pada kepuasan nasabah.

\section{Social Value dan Satisfaction (Kepuasan)}

$\mathrm{H}_{0} 1 \mathrm{c}$ : Social Value tidak berpengaruh positif pada kepuasan nasabah.

H1c: Social Value berpengaruh positif pada kepuasan nasabah.

\section{Satisfaction (Kepuasan) dan Loyalty (Kesetiaan)}

$\mathrm{H}_{0}$ 2: Kepuasan tidak berpengaruh positif pada kesetiaan nasabah.

$\mathrm{H} 2$ : Kepuasan berpengaruh positif pada kesetiaan nasabah.

Penelitian ini menggunakan model penelitian seperti di bawah ini:

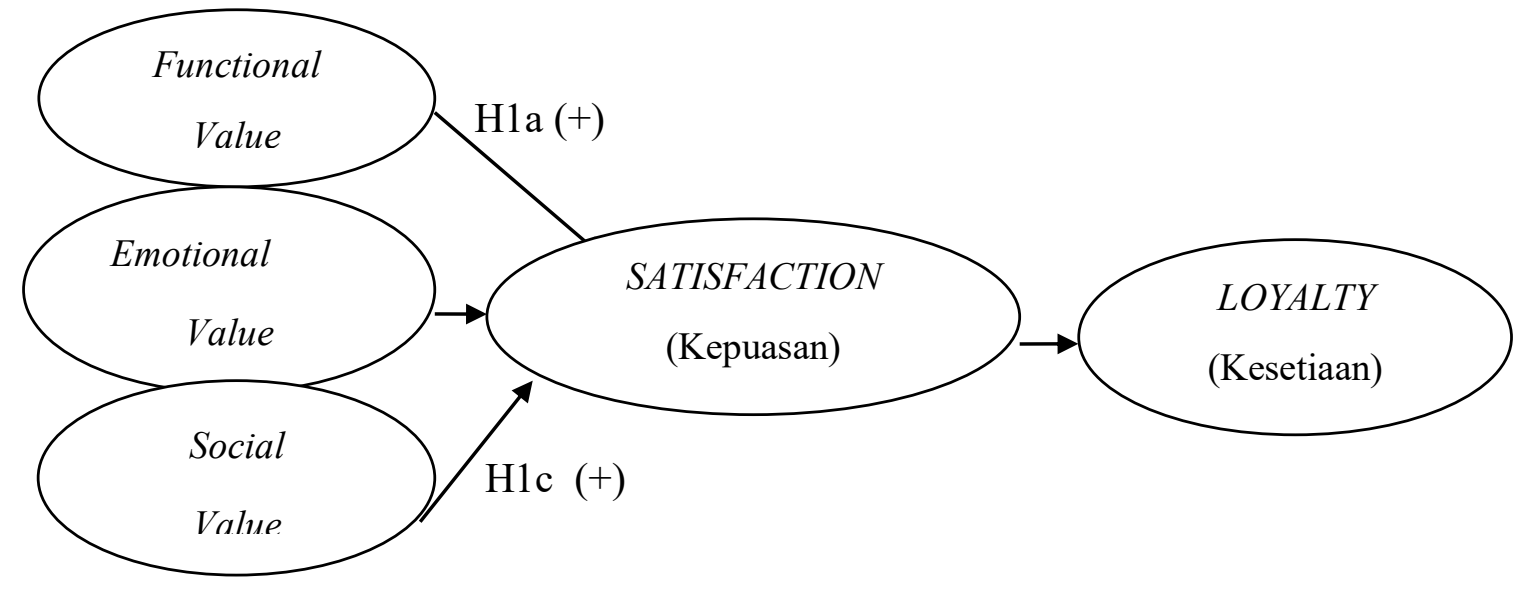

Gambar 1. Pengaruh CPV pada Kepuasan dan Kesetiaan

(Sumber: Boonlertvanich, 2011)

Keterangan:

H1a (+) : Functional Value berpengaruh positif pada kepuasan nasabah

$\mathrm{H} 1 \mathrm{~b}(+)$ : Emotional Value berpengaruh positif pada kepuasan nasabah

H1c (+) : Social Value berpengaruh positif pada kepuasan nasabah

$\mathrm{H} 2(+)$ : Kepuasan berpengaruh positif pada kesetiaan nasabah

\section{METODE PENELITIAN}

\section{Populasi dan Besaran Sampel}

Populasi dalam penelitian ini adalah semua nasabah Bank BRI Syariah Kantor Cabang Wahid Hasyim. Pengambilan sampel dilakukan dengan menggunakan teknik non probability 
sampling, yaitu convenience sampling. Penarikan sampel dalam penelitian ini dilakukan di Banking Hall Bank BRI Syariah Kantor Cabang Wahid Hasyim dengan meminta nasabah untuk mengisi kuisioner dan mengambil kembali kuisioner yang telah diisi tersebut untuk selanjutnya dilakukan pengolahan data. Jumlah sampel yang diambil dalam penelitian ini sebanyak 200 nasabah Bank BRI Syariah Kantor Cabang Wahid Hasyim.

Menurut Hair et al. (1995), menemukan bahwa ukuran sampel yang sesuai dalam penelitian adalah sebesar $100-200$.

\section{Definisi Operasional Variabel dan Pengujian Instrumen}

\section{Customer Perceived Value (CPV)}

Merupakan sekumpulan nilai atau manfaat yang diharapkan akan diperoleh nasabah selaku responden pada penelitian ini dari produk atau jasa yang ditawarkan oleh Bank. Customer perceived value yang harus diperoleh nasabah yaitu functional value, emotional value, dan social value. Nilai total pelanggan (Total Customer Value) merupakan total dari semua nilai produk, jasa, personil, dan citra yang diterima nasabah dari tawaran yang diberikan oleh Bank. Jumlah nilai bagi nasabah ini dapat berupa nilai produk, nilai pelayanan, nilai karyawan, dan nilai citra. Nilai produk misalnya manfaat yang lebih dari suatu produk yang ditawarkan oleh bank. Nilai pelayanan misalnya keramahan karyawan dalam melayani nasabah. Nilai karyawan misalnya kerapihan dalam berpenampilan dan cara bicara yang sopan. Nilai citra sama dengan image perusahaan.

\section{Customer Satisfaction (Kepuasan Nasabah)}

Kepuasan adalah perasaan senang atau kecewa seseorang yang muncul setelah membandingkan antara kinerja (hasil) produk/layanan yang dipikirkan terhadap kinerja (hasil) yang diharapkan. Jika kinerja berada dibawah harapan, nasabah tidak puas. Jika kinerja memenuhi harapan, nasabah puas. Jika kinerja melebihi harapan, nasabah amat puas atau senang. Kepuasan merupakan suatu proses yang dinamis dan harus selalu dipantau secara berkala oleh institusi Bank. Pengukuran kepuasan nasabah pada akhirnya menjadi suatu kebutuhan dalam institusi Bank karena seperti diungkapkan sebelumnya bahwa tujuan didirikannya suatu Bank adalah untuk memberikan yang terbaik bagi nasabah. 


\section{Customer Loyalty (Kesetiaan Nasabah)}

Kesetiaan merupakan dorongan perilaku untuk melakukan pembelian berulang pada produk/layanan perbankan. Kesetiaan nasabah tidak serta merta tercipta begitu saja, namun memakan waktu yang relatif cukup lama. Kesetiaan nasabah muncul ketika sudah tercipta suatu hubungan yang dekat antara personil institusi Bank dengan nasabahnya, Bank memahami apa yang diinginkan dan dibutuhkan oleh nasabahnya, selain itu dari pihak perusahaan selalu menanggapi dengan cepat respon yang diberikan oleh nasabah serta melayani nasabah dengan sepenuh hati. Kesetiaan membawa dampak baik bagi institusi Bank untuk jangka waktu yang lama. Oleh karena itu, setiap Bank berusaha untuk memperbaiki layanan maupun produk yang diberikan untuk nasabah, demi terciptanya loyalitas nasabah. Loyalitas nasabah merupakan salah satu faktor yang memberikan kontribusi yang signifikan terhadap profitabilitas perusahaan.

\section{Pengujian Instrumen Penelitian}

Data penelitian tidak akan berguna apabila instrumen pengukuran yang digunakan tidak menunjukkan validitas dan reliabel yang tinggi. Oleh karena itu, pengujian validitas dan reliabilitas terhadap instrumen penelitian perlu dilakukan pada awal penelitian.

\section{Uji Validitas (Validity Test)}

Dalam penelitian ini pengujian validitas dilakukan untuk mengukur apakah pertanyaan dalam kuisioner yang diberikan pada responden dapat mengukur apa yang hendak diukur sehingga dapat menjawab tujuan dari penelitian. Uji validitas yang dilakukan pada penelitian ini menggunakan analisis faktor (Factor Analysis). Signifikansi analisis faktor ini menggunakan metode practical significance, yaitu jika factor loading $\pm 0,50$ atau lebih besar, maka dipertimbangkan signifikan (Hair et al., 1995). Nilai loading factor menunjukkan hubungan antara variabel dengan common factor ( Nugroho, 2011). Uji validitas dalam penelitian ini menggunakan responden sebanyak 30 responden dan selanjutnya dilakukan pengujian pada data yang diperoleh. Apabila hasilnya valid berarti tidak perlu dilakukan pengujian ulang. Hasil uji validitas pada penelitian ini menunjukkan bahwa terdapat satu butir pertanyaan yang dibuang atau dikeluarkan dari daftar pertanyaan yang ada di kuisioner dikarenakan nilai corrected item - total correlation sebesar 0,131 dimana nilai tersebut berada di bawah nilai 0,240 . Sedangkan untuk butir yang lain nilai corrected item - total correlation berada diatas nilai 0,240 sehingga tidak ada lagi butir pertanyaan yang harus dikeluarkan dari daftar pertanyaan kuisioner (Sarwono,2012). Berdasarkan hasil uji validitas menggunakan 
analisis faktor diketahui bahwa factor loading untuk variabel Emotional Value(EV) berkisar antara 0,587 - 0,789, variabel Loyalty (LOY) berkisar antara 0,605-0,787, variabel Functional Value $(F V)$ berkisar antara 0,611 - 0,705, variabel Satisfaction (SAT) berkisar 0,557 - 577, variabel Social Value (SV) berkisar antara 0,500 - 0,807. Hasil uji validitas terhadap butir-butir pertanyaan yang telah dilakukan dengan bantuan program SPPS for Windows versi 20 dapat diketahui bahwa semua butir pertanyaan dalam penelitian ini adalah valid dan layak digunakan sebagai alat pengumpul data. Hal ini dikarenakan factor loading yang diperoleh $\pm 0,50$ atau lebih besar (Hair et al., 1995).

\section{Uji Reliabilitas (Reliability Test)}

Uji reliabilitas ini digunakan untuk menunjukkan sejauh mana alat ukur dapat diandalkan. Suatu instrumen dikatakan reliable apabila alat ukur tersebut menghasilkan hasilhasil yang konsisten, dengan demikian reliabilitas menunjukkan sejauh mana pengukuran dapat memberikan hasil yang relatif tidak berbeda. Pengujian reliabilitas dilakukan dengan menggunakan koefisien Cronbach Alpha. Nilai Rule of Thumb yang digunakan untuk menilai Cronbach Alpha harus lebih besar dari 0,7 meskipun nilai 0,6 masih dapat diterima (Hair et al., 1998). Reliabilitas dinyatakan dengan koefisien alpha yang mempunyai rentang antara 0 sampai dengan 1. Semakin mendekati angka 1 berarti semakin tinggi reliabilitasnya (Sekaran, 2006). Uji reliabilitas pada penelitian ini menggunakan responden sebanyak 30 responden, yang untuk selanjutnya dilakukan pengujian terhadap data yang diperoleh. Apabila hasilnya valid berarti tidak perlu dilakukan pengujian ulang. Uji reliabilitas pada penelitian ini menggunakan SPSS for windows versi 20. Dari hasil uji reliabilitas yang dilakukan, diketahui bahwa nilai koefisien cronbach alpha hampir semuanya berada diatas nilai rule of thumb yaitu diatas 0,7. Sehingga, dari hasil uji validitas dan reliabilitas pada penelitian ini terlihat bahwa instrumen dalam penelitian ini valid dan reliabel.

\section{HASIL DAN PEMBAHASAN}

Dalam penelitian ini, pengumpulan data dilakukan dengan cara membagikan kuisioner secara langsung kepada responden. Kuisioner yang dianalisis pada penelitian ini sebanyak 200 kuisioner. Responden yang dipilih adalah responden yang telah menjadi nasabah Bank BRI Syariah Kantor Cabang Wahid Hasyim. Analisis deskriptif pada penelitian ini menggunakan rata-rata atau mean. Menurut Dajjan (1992) dalam Wijaya (2012), nilai rata-rata dari masingmasing jawaban responden dapat dikelompokkan ke dalam kelas interval. 


\section{Deskripsi Data}

Berdasarkan dari hasil analisis statistik deskriptif, dapat diketahui nilai rata-rata (mean) total untuk variabel Functional Value (FV) sebesar 3,9803. Nilai rata-rata (mean) tersebut berada pada skala 3,40 - 4,19. Sehingga dari hasil tersebut, dapat dikatakan bahwa variabel Functional Value $(F V)$ merupakan nilai yang diharapkan tinggi oleh nasabah Bank BRISyariah Kantor Cabang Wahid Hasyim untuk dapat terpenuhi.

Nilai rata-rata (mean) total untuk variabel Emotional Value (EV) sebesar 4,1470. Nilai rata-rata (mean) tersebut berada di skala 3,40 - 4,19. Sehingga hal ini berarti bahwa variabel Emotional Value(EV) merupakan nilai yang diharapkan tinggi oleh nasabah Bank BRISyariah Kantor Cabang Wahid Hasyim.

Nilai rata-rata (mean) variabel Social Value (SV) sebesar 3,7900. Hal ini berarti Social Value $(S V)$ berada di skala 3,40 - 4,19 yang artinya variabel ini merupakan nilai yang diharapkan terpenuhi oleh nasabah Bank BRISyariah Kantor Cabang Wahid Hasyim.

Nilai rata-rata (mean) variabel Satisfaction (SAT) sebesar 4,1700. Hal ini berarti Satisfaction (SAT) berada di skala 3,40 - 4,19 yang artinya kepuasan nasabah Bank BRISyariah Kantor Cabang Wahid Hasyim tergolong tinggi.

Nilai rata-rata (mean) total untuk variabel Loyalty (LOY) sebesar 3,9694. Hal ini berarti Loyalty (LOY) berada diatas skala 3,40 - 4,19, yang artinya kesetiaan nasabah Bank BRISyariah Kantor Cabang Wahid Hasyim tinggi.

Tabel 1. Korelasi

\begin{tabular}{|l|l|l|l|l|l|}
\hline & FV & EV & SV & SAT & LOY \\
\hline FV & 1,000 & 0,819 & 0,731 & 0,846 & 0,797 \\
\hline EV & 0,819 & 1,000 & 0,647 & 0,832 & 0,726 \\
\hline SV & 0,731 & 0,647 & 1,000 & 0,691 & 0,597 \\
\hline SAT & 0,846 & 0,832 & 0,691 & 1,000 & 0,788 \\
\hline LOY & 0,797 & 0,726 & 0,597 & 0,788 & 1,000 \\
\hline
\end{tabular}


Tabel 2. Hasil Regresi

(Regresi Pengaruh Customer Perceived Value pada Kepuasan)

\begin{tabular}{|c|c|l|c|c|c|}
\hline $\begin{array}{c}\text { Variabel } \\
\text { Independen }\end{array}$ & $\begin{array}{c}\text { Variabel } \\
\text { Dependen }\end{array}$ & R Square & $\boldsymbol{B}$ & t hitung & P value \\
\hline FV & \multirow{2}{*}{0,781} & 0,432 & 6,585 & 0,000 \\
EV & SAT & 0,406 & 6,916 & 0,000 \\
SV & & & 0,112 & 2,267 & 0,024 \\
\hline
\end{tabular}

(Sumber : Data Primer Diolah, 2012)

Tabel 3. Hasil Regresi

(Regresi Kepuasan pada Kesetiaan)

\begin{tabular}{|c|c|l|c|c|c|}
\hline $\begin{array}{c}\text { Variabel } \\
\text { Independen }\end{array}$ & $\begin{array}{c}\text { Variabel } \\
\text { Dependen }\end{array}$ & Square & $\boldsymbol{B}$ & t hitung & P value \\
\hline SAT & LOY & 0,621 & 0,788 & 18,005 & 0,000 \\
\hline
\end{tabular}

(Sumber : Data Primer Diolah, 2012)

Dari Tabel 1 di atas, dapat diketahui korelasi atau hubungan antar variabel dalam penelitian ini, yaitu hubungan antara functional value, emotional value, social value dengan kepuasan nasabah. Hal ini dilakukan karena untuk menganalisis regresi perlu diketahui dahulu besar korelasinya. Besar korelasi antara variabel functional value dan kepuasan nasabah ditunjukkan dengan nilai $\mathrm{R}=0,846$, dan nilai signifikansi $(\mathrm{p})=0,000$. Karena nilai signifikansinya $<0,01$, artinya terdapat hubungan yang signifikan antara functional value dan kepuasan. Demikian halnya dengan dua variabel yang lain, yaitu hubungan emotional value dengan kepuasan nasabah dan hubungan social value dengan kepuasan nasabah. Hubungan emotional value dengan kepuasan nasabah ditunjukkan dengan besarnya nilai $\mathrm{R}=0,832$ dan signifikansi $(p)=0,000$. Dan hubungan social value dengan kepuasan ditunjukkan dengan besarnya nilai $\mathrm{R}=0,691$ dengan signifikansi $(\mathrm{p})=0,000$. Sehingga dapat dikatakan bahwa dilihat dari hasil korelasinya ketiga variabel berkorelasi secara signifikan terhadap kepuasan.

Dari Tabel 1 di atas dapat terlihat hubungan antar variabel penelitian yaitu hubungan antara kepuasan dan kesetiaan nasabah. Besar korelasi antar variabel kepuasan dan kesetiaan nasabah ditunjukkan dengan besarnya nilai $\mathrm{R}=0,788$ dan signifikansi $(\mathrm{p})=0,000$. Karena nilai 
signifikansinya $<0,01$, maka dapat dikatakan bahwa terdapat hubungan yang signifikan antara kepuasan dan kesetiaan nasabah.

\section{Hasil Pengujian Hipotesis}

Dalam penelitian ini analisisnya menggunakan analisis regresi. Menurut Kuncoro (2009), dalam analisis regresi terdapat tiga jenis kriteria ketepatan (goodness of fit) yaitu : 1) uji statistik t; 2) uji statistik F; dan 3) koefisien determinasi. Penelitian ini menggunakan uji statistik t (t-test). Menurut Hair et al. (2006), pengujian dilakukan untuk melihat kuat tidaknya pengaruh masing-masing variabel bebas terhadap variabel terikat (secara parsial).

\section{Uji Hipotesis Pertama}

Uji hipotesis pertama pada penelitian ini menggunakan analisis regresi linier berganda. Terdapat tiga variabel independen yaitu functional value, emotional value, social value, serta satu variabel dependen yaitu kepuasan nasabah.

Ketepatan fungsi regresi yang digunakan dalam penelitian ini dapat diukur dengan koefisien determinasi, nilai statistik F dan nilai statistik t. Dari hasil analisis regresi yang telah dilakukan, diketahui bahwa dari perhitungan nilai regresi diperoleh $R$ square sebesar 0,781 . Nilai ini menunjukkan bahwa kemampuan variabel-variabel independen (functional value, emotional value, dan social value) dapat menjelaskan variabel dependennya (kepuasan nasabah). Nilai koefisien determinasi ( $R$ square) menunjukkan kemampuan model dalam menjelaskan variabel bebas. Nilai 0,781 berarti bahwa sekitar 78,1\% kepuasan nasabah dipengaruhi oleh tiga dimensi tersebut diatas yakni functional value, emotional value dan social value, sedangkan sisanya sebesar 21,9 \% (yang diperoleh dari 100\% - 78,1 \% = 21,9\%) dipengaruhi oleh faktor-faktor lain. Standard error of the estimate adalah sebesar 0,23601 lebih kecil dibandingkan dengan standard deviasi kepuasan nasabah yaitu sebesar 0,50013 yang artinya model regresi lebih bagus dalam berperan sebagai prediktor kepuasan nasabah itu sendiri.

Dari hasil analisis regresi dapat diketahui bahwa F hitung sebesar 232,548 dengan nilai signifikansi (p) sebesar 0,000 . Nilai signifikansi $<0,01$ artinya terdapat pengaruh signifikan secara bersama-sama dari customer perceived value (functional value, emotional value dan social value) berpengaruh secara signifikan pada kepuasan nasabah.

Dari Tabel 2 dapat diketahui bahwa telah dilakukan uji t dalam penelitian ini. Dari tabel tersebut dapat terlihat bahwa telah diperoleh nilai Standardized Coefficient Beta dimensi Functional Value sebesar 0,432. Nilai ini menunjukkan tingkat korelasi antara Functional 
Value dengan Kepuasan Nasabah. Demikian pula dengan dimensi yang lain yaitu Standardized Coefficient Beta dimensi Emotional Value sebesar 0,406 dan Standardized Coefficient Beta dimensi Social Value sebesar 0,112. Nilai-nilai tersebut menunjukkan tingkat korelasi antara Emotional Value dengan Kepuasan Nasabah dan Social Value dengan Kepuasan Nasabah.

Lalu nilai t yang diperoleh merupakan nilai yang berguna untuk pengujian, dalam penelitian ini. Nilai t berguna untuk menguji apakah pengaruh Functional Value, Emotional Value dan Social Value terhadap Kepuasan Nasabah benar-benar signifikan atau tidak. Berdasarkan tabel diatas diperoleh hasil untuk Functional Value nilai t sebesar 6,585 dan signifikansi (p) sebesar 0,000, dimana nilai signifikansi ini $<0,05$ sehingga terdapat pengaruh yang signifikan dari Functional Value terhadap Kepuasan. Kemudian untuk Emotional Value memiliki nilai t sebesar 6,916 dengan signifikansi (p) sebesar 0,000, dimana nilai signifikansi ini nilainya $<0,05$ sehingga terdapat pengaruh yang signifikan dari Emotional Value terhadap Kepuasan Nasabah. Dan selanjutnya Social Value memiliki nilai t sebesar 2,267 dengan nilai signifikansi (p) sebesar 0,024, dimana nilai signifikansi ini nilainya masih $<0,05$ sehingga terdapat pengaruh yang signifikan dari Social Value terhadap Kepuasan Nasabah.

\section{Uji Hipotesis 1a}

Hipotesis yang pertama dalam penelitian ini adalah sebagai berikut:

\section{Ho1a : Functional Value tidak berpengaruh positif pada Kepuasan nasabah. H1a : Functional Value berpengaruh positif pada Kepuasan nasabah.}

Hipotesis ini diuji dengan menggunakan uji t. Berdasarkan Tabel 4.2 dapat diketahui bahwa nilai p ( $P$ Value) untuk variabel Functional Value adalah sebesar 0,000. Nilai ini berada di bawah level of confidence 0,05 ( $\mathrm{p}<0,05)$, dan nilai Standardized Coefficient Beta variabel ini sebesar 0,432. Dalam hal ini H1a yang berasumsi bahwa Functional Value berpengaruh positif terhadap Kepuasan Nasabah diterima, sedangkan $\mathrm{H}_{0}$ la ditolak. Maka uji $\mathrm{t}$ ini menunjukkan bahwa Functional Value berpengaruh secara signifikan terhadap Kepuasan nasabah Bank BRISyariah Kantor Cabang Wahid Hasyim.

\section{Uji Hipotesis 1b}

Hipotesis $1 \mathrm{~b}$ dalam penelitian ini adalah sebagai berikut:

\section{Ho1b : Emotional Value tidak berpengaruh positif pada Kepuasan nasabah. \\ H1b : Emotional Value berpengaruh positif pada Kepuasan nasabah.}


Hipotesis ini juga diuji dengan menggunakan uji t. Berdasarkan Tabel 4.2 dapat diketahui bahwa nilai p ( $P$ Value) untuk variabel Emotional Value adalah sebesar 0,000. Nilai ini berada di bawah level of confidence 0,05 ( $\mathrm{p}<0,05)$, dan nilai Standardized Coefficient Beta variabel ini sebesar 0,406. Dalam hal ini, hipotesis H1b yang berasumsi bahwa Emotional Value berpengaruh positif terhadap Kepuasan Nasabah diterima, dan $\mathrm{H}_{0} 1 \mathrm{~b}$ ditolak. Maka dari uji t yang telah dilakukan, menunjukkan bahwa Emotional Value berpengaruh secara signifikan terhadap Kepuasan nasabah Bank BRISyariah Kantor Cabang Wahid Hasyim.

\section{Uji Hipotesis 1c}

Hipotesis 1c dalam penelitian ini adalah sebagai berikut:

\section{Ho1c : Social Value tidak berpengaruh positif pada Kepuasan nasabah. \\ H1b : Social Value berpengaruh positif pada Kepuasan nasabah.}

Sama seperti halnya pada hipotesis sebelumnya, hipotesis ini juga diuji dengan menggunakan uji t. Berdasarkan Tabel 4.2 dapat diketahui bahwa nilai p (P Value) untuk variabel Social Value adalah sebesar 0,024. Nilai ini masih berada di bawah level of confidence $0,05(p<0,05)$, dan nilai Standardized Coefficient Beta variabel ini sebesar 0,112. Dalam hal ini, hipotesis H1c yang berasumsi bahwa Social Value berpengaruh positif terhadap Kepuasan Nasabah diterima, sedangkan $\mathrm{H}_{0} 1 \mathrm{c}$ ditolak. Maka dari uji t yang telah dilakukan, menunjukkan bahwa Social Value berpengaruh secara signifikan terhadap Kepuasan nasabah Bank BRI Syariah Kantor Cabang Wahid Hasyim.

\section{Uji Hipotesis Kedua}

Uji hipotesis kedua pada penelitian ini menggunakan analisis regresi linier berganda. Terdapat satu buah variabel independen yaitu Kepuasan Nasabah serta satu buah variabel dependen yaitu Kesetiaan Nasabah.

Sama halnya dengan hipotesis yang pertama, bahwa hasil regresi menunjukkan perhitungan nilai regresi dan diperoleh $R$ square sebesar 0,621. Nilai ini menunjukkan kemampuan variabel independen (Kepuasan Nasabah) dapat menjelaskan variabel dependen (Kesetiaan Nasabah). Nilai koefisien determinasi ( $R$ square) menunjukkan kemampuan model dalam menjelaskan variabel bebas. Nilai 0,621 berarti bahwa sekitar 62,1\% kesetiaan nasabah dipengaruhi oleh kepuasan nasabah, sedangkan sisanya sebesar 37,9 \% (yang diperoleh dari 100\% - 62,1\%= $37,9 \%$ ) dipengaruhi oleh faktor-faktor lain. Standard error of the estimate adalah sebesar 0,34143. Nilai ini lebih kecil bila dibandingkan dengan standard deviasi kesetiaan nasabah yaitu 
sebesar 0,55309 yang artinya model regresi lebih bagus dalam berperan sebagai prediktor kesetiaan nasabah itu sendiri.

Dari hasil regresi menunjukkan bahwa telah dilakukan uji $\mathrm{F}$ dimana diperoleh nilai $\mathrm{F}$ hitung sebesar 324,184 dengan nilai signifikansi (p) sebesar 0,000. Nilai signifikansi tersebut besarnya $<0,01$ artinya terdapat pengaruh yang signifikan secara bersama-sama dari kepuasan nasabah yang berpengaruh secara signifikan terhadap kesetiaan nasabah.

Tabel 4.3 menunjukkan bahwa telah dilakukan uji t dalam penelitian ini. Dari tabel tersebut dapat terlihat bahwa diperoleh nilai Standardized Coefficient Beta yang dimiliki oleh variabel Kepuasan Nasabah sebesar 0,788. Nilai ini menunjukkan tingkat korelasi antara Kepuasan Nasabah dengan Kesetiaan Nasabah. Lalu nilai t yang diperoleh merupakan nilai yang berguna untuk pengujian, dalam penelitian ini. Nilai t berguna untuk menguji apakah pengaruh Kepuasan Nasabah terhadap Kesetiaan Nasabah benar-benar signifikan atau tidak. Berdasarkan tabel diatas diperoleh hasil bahwa Kepuasan Nasabah memiliki nilai t sebesar 18,005 dan signifikansi (p) sebesar 0,000, dimana nilai signifikansi ini $<0,05$ sehingga terdapat pengaruh yang signifikan dari Kepuasan Nasabah terhadap Kesetiaan Nasabah.

Hipotesis yang kedua dalam penelitian ini adalah sebagai berikut :

\section{$\mathrm{H}_{02}$ : Kepuasan tidak berpengaruh positif pada Kesetiaan nasabah.}

H2 : Kepuasan berpengaruh positif pada Kesetiaan nasabah.

Pada hipotesis kedua ini dilakukan perlakuan yang sama dengan hipotesis-hipotesis sebelumnya, yaitu diuji dengan menggunakan uji t. Berdasarkan tabel 4.3 dapat diketahui bahwa nilai p ( $P$ Value) untuk variabel Kepuasan Nasabah adalah sebesar 0,000. Nilai ini berada di bawah level of confidence 0,05 $(\mathrm{p}<0,05)$, dan nilai Standardized Coefficient Beta variabel ini sebesar 0,788. Dalam hal ini Hipotesis H2 yang berasumsi bahwa Kepuasan Nasabah berpengaruh positif terhadap Kesetiaan Nasabah dapat diterima, sedangkan $\mathrm{H}_{0} 2$ ditolak. Maka dari uji $\mathrm{t}$ yang telah dilakukan menunjukkan bahwa Kepuasan Nasabah berpengaruh secara signifikan terhadap Kesetiaan Nasabah Bank BRISyariah Kantor Cabang Wahid Hasyim.

\section{KESIMPULAN DAN SARAN}

\section{Kesimpulan}

Penelitian ini meneliti mengenai pengaruh Customer Perceived Value pada Kepuasan dan Kesetiaan Nasabah Bank BRISyariah Kantor Cabang Jakarta Wahid Hasyim. Menurut Sheth et. al., (1991) dalam Sumarto (2007), terdapat tiga nilai penting yang harus diperoleh 
nasabah yaitu Functional Value, Emotional Value, dan Social Value. Hasil dari penelitian ini menunjukkan bahwa ketiga nilai penting tersebut berhasil didapatkan oleh nasabah Bank BRISyariah Kantor Cabang Wahid Hasyim sehingga nasabah berhasil merasakan nilai-nilai yang diinginkan, maka selanjutnya terdapat pengaruh Customer Perceived Value pada Kepuasan dan Kesetiaan Nasabah Bank BRISyariah Kantor Cabang Jakarta Wahid Hasyim.

Dari hasil penelitian uji sampel kecil, butir-butir pertanyaan yang terdapat pada kuisioner yang diisi responden valid dan reliabel. Namun, pada hasil uji validitas terdapat satu butir pertanyaan yang dibuang atau dikeluarkan dari daftar pertanyaan dikarenakan nilai corrected item - total correlation berada dibawah nilai yang seharusnya.

Hasil pengujian hipotesis 1a menunjukkan bahwa Functional Value berpengaruh positif secara signifikan pada Kepuasan Nasabah Bank BRI Syariah Kantor Cabang Wahid Hasyim. Hipotesis 1 b menunjukkan bahwa Emotional Value berpengaruh positif secara signifikan pada Kepuasan Nasabah Bank BRI Syariah Kantor Cabang Wahid Hasyim. Hipotesis 1c menunjukkan bahwa Social Value berpengaruh positif secara signifikan pada Kepuasan Nasabah Bank BRI Syariah Kantor Cabang Wahid Hasyim. Dan untuk hipotesis 2 menunjukkan bahwa Kepuasan berpengaruh positif secara signifikan pada Kesetiaan Nasabah Bank BRI Syariah Kantor Cabang Wahid Hasyim. Secara keseluruhan, hasil dari penelitian ini menunjukkan bahwa Customer Perceived Value berpengaruh positif pada Kepuasan dan Kesetiaan Nasabah Bank BRISyariah Kantor Cabang Wahid Hasyim.

\section{Saran}

Hasil penelitian menunjukkan bahwa customer perceived value dapat mempengaruhi kepuasan nasabah Bank BRISyariah Kantor Cabang Wahid Hasyim yang pada akhirnya akan membentuk kesetiaan nasabah. Untuk itu, sebaiknya dari awal seorang banker harus dapat membuat suatu strategi yang tepat guna yang nantinya dapat digunakan untuk meningkatkan nilai pada produk/layanan yang ditawarkan oleh suatu Bank. Selain itu, seorang banker juga harus mengetahui nilai-nilai apa yang sebenarnya diinginkan oleh nasabah. Sehingga sebuah bank dapat memenuhi nilai-nilai yang diinginkan oleh para nasabahnya sehingga nasabah akan puas dan pada akhirnya terciptalah kesetiaan terhadap bank tersebut. Sebuah Bank, baik itu Bank Umum ataupun Bank Syariah harus mengetahui nilai-nilai yang diharapkan oleh nasabahnya, sehingga pihak Bank dapat memenuhi harapan setiap nasabah yang pada akhirnya akan berpengaruh pada kepuasan nasabah serta kesetiaan nasabah Bank tersebut. 
Berdasarkan keterbatasan dalam penelitian ini, penulis menyarankan beberapa hal untuk dijadikan sebagai usulan penelitian di masa yang akan datang. Perlu untuk diteliti lebih lanjut mengenai pengaruh Customer Perceived Value pada kepuasan dan kesetiaan nasabah pembiayaan pada Bank Syariah. Masih banyak aspek-aspek yang perlu digali lagi lebih lanjut tentang topik ini. Dan untuk selanjutnya diharapkan agar penelitian ini dan penelitian sejenis dapat berguna bagi dunia perbankan dalam memenuhi setiap keinginan dan kebutuhan para nasabahnya.

\section{DAFTAR PUSTAKA}

Ardhanari M., (2008). “Customer Satisfaction Pengaruhnya Terhadap Brand Preference Dan Repurchase Intention Private Brand", Jurnal Riset Ekonomi dan Bisnis, Volume 8, Nomor 2.

Boonlertvanich, K. (2011). "Effect of Customer Perceived Value on Satisfaction and Customer Loyalty in Banking Service : The Moderating Effect of Main Bank Status", International Journal of Business Research, Volume 11, Number 6.

Cronin J. Jr., Brady, M. and Hult, T. (2000). “Assessing the Effects of Quality, Value, and Customer Satisfaction on Consumer Behavioural Intentions in Service Environments", Journal of Retailing, Volume 76, Number 2.

Daryanto, (2011), “Sari Kuliah Manajemen Pemasaran”, Satu Nusa, Bandung.

Dodds, W. B., Monroe, K.B. and Grewal, D. (1991), "The Effect of Price, Brand and Store Information on Buyers Product Evaluations”, Journal of Marketing Research, Vol. 28.

Hair, J. F., Anderson, R. E., Tatham, R. L., and Black, W. C., (1995). "Multivariate Data Analysis”, Englewood Cliffs, NJ: Prentice Hall.

Hair, Joseph. F. Jr., Ralph E. Anderson, Ronald L. Tatham, William C. Block, (2006). “Multivariate Data Analysis”, Upper Saddle River, New Jersey, Prentice Hall Int. Inc.

Kotler, P., \& Keller K.L., (2006). "Marketing Management", $12^{\text {th }}$ edition, Prentice Hall, New Jersey.

Kuncoro M, (2009). "Metode Riset untuk Bisnis \& Ekonomi: Bagaimana Meneliti \& Menulis Tesis”, edisi 3, Penerbit Erlangga.

Monroe, K., (1990). “Pricing: Making Profitable Decisions”, McGraw-Hill, New York, NY. Nugroho, Y A, (2011). “It's Easy :Olah Data Dengan SPSS”, Skripta.

Oliver, Richard L. and Wayne S. deSarbo, (1988). "Response Determinants in Satisfaction Judgements", Journal of Consumer Research, Volume 14, Number 4. 
Parasuraman A., (1997). "Reflections on Gaining Competitive Advantage Through Customer Value," Academy of Marketing Science Journal.

Rama A, (2012). “Proyeksi Perbankan Syariah 2012”, tanggal 3 Januari 2012.

Roig, Juan Carlos Fandos, Javier Sanchez Garcia, Miguel Angel Moliner Tena, and Jaume Liorens Monzoins, (2006). "Customer Perceived Value in Banking Services", International Journal of Bank Marketing, Volume 24, Number 5.

Sarwono J., (2012). "Metode Riset Skripsi: Pendekatan Kuantitatif Menggunakan Prosedur SPSS: Tuntunan Praktis dalam Menyusun Skripsi”, PT. Elex Media Komputindo.

Sekaran U, (2006). “Research Methods for Business”, edisi 4, Salemba Empat Jakarta.

Spreng, R.A., MacKenzie, S. B., and Olshavsky, R.W., (1996).“A re-examination of the Determinants of Consumer Satisfaction," Journal of Marketing, Volume 60.

Sumarto, (2007). "Membangun Customer Loyalty Nasabah Bank Melalui Customer Satisfaction", Jurnal Riset Ekonomi dan Bisnis, Volume 7, Nomor 2.

Sumarwan U,(2004). “Merek Populer Belum Tentu Dikonsumsi”, Majalah Infobis, Edisi Bulan Maret.

Sumarwan, U.; Jauzi, A.; Mulyana, A.; Karno, B.N.; Mawardi, P. K.; Nugroho, W., (2011), "Riset Pemasaran dan Konsumen. Panduan Riset dan Kajian : Kepuasan, Perilaku Pembelian, Gaya Hidup, Loyalitas dan Persepsi Risiko”, IPB Press, Bogor.

Tse, David K., and Peter C. Wilson,(1988). "Models of Consumer Satisfaction Formation : An Extention," Journal of Marketing Research.

Wijaya, T.,(2012). "Praktis \& Simpel: Cepat Menguasai SPSS 20 untuk Olah Data \& Interpretasi Data, Data Penelitian \& Skripsi”, Cahaya Atma Pustaka.

Woodruff, R.B.,(1997)."Customer Value: The Next Source for Competitive Advantage," Academy of Marketing Science Journal.

Zeithaml, Valarie A., (1988). “Consumer Perceptions of Price, Quality, and Value: A MeansEnd Model and Synthesis of Evidence", Journal of marketing, Volume 52, Number 3.

Zeithaml, Valarie A., Leonard L. Berry and A. Parasuraman, (1996). "The Behavioral Consequences of Service Quality", Journal of Marketing, Volume 60, Number 2.

Zeithaml, V.A. and Bittner, M.J., (2003). "Services Marketing: Integrating Customer Focus Across The Firm, $3^{\text {rd }}$ Edition, New York: The McGraw Hill Companies, Inc.

Zubaedah L.M., (2012). “ Analisis Pengaruh Customer Perceived Value Pada Kepuasan Dan Kesetiaan Nasabah Bank BRI Syariah Kantor Cabang Jakarta Wahid Hasyim”, Tesis MM UGM. 